\title{
Endometritis in mares experimentally infected with three different strains of $E$. coli
}

\author{
Giovani C. Camozzato', Nicolás Cazales',2, Eduardo M. Pinheiro', Caroline A. Wolfl', Petra Garbadel, Maria I. M. Jobim?', Ricardo \\ M. Gregory and Rodrigo C. Mattos ${ }^{\prime}$ \\ 1 REPROLAB, Faculdade de Veterinária, UFRGS, Porto Alegre, Brazil \\ 2 Faculdade de Veterinária, UDELAR/CAPES, Montevideo, Uruguay
}

\begin{abstract}
Summary: The aim of this study was to describe the inflammatory response after intrauterine inoculation with three different strains of $\mathrm{E}$. coli in the mare. Nine cyclic mares aged between 7 and 20 years old were selected and their estrous detected by transrectal palpation and ultrasound. Only clinically normal mares with negative cytology and bacteriology were used. Three different strains of E. coli obtained from: (UT) uterine swab of a mare with endometritis, (VE) vestibular swab from a healthy mare and (MA) from mare manure, were used. Subsequently, the mares were submitted to intrauterine inoculation with $3 \times 109 \mathrm{E}$. coli of one of the three different strains. All mares were challenged with each strain of $\mathrm{E}$. coli in a randomized order in the subsequent different cycles. One day after infection, clinical examination of the genital tract by speculum, ultrasound, endometrial cytology and bacteriological cultures were performed. These procedures were repeated daily until negative culture and negative cytology were diagnosed. All mares had slight ( $<10 /$ field) to severe ( $>20 /$ field) endometrial neutrophils $24 \mathrm{~h}$ after E. coli inoculation. In 25 of 27 mares (92.6\%), vaginal clinical signs and intrauterine fluid (IUF) were detected. Severe vaginal signs with purulent aspect and hyperemic mucosa were observed in 17 mares and 8 presented mild signs. Only $59.2 \%$ of the mares $(16 / 27)$ were E. coli positive $24 \mathrm{~h}$ after the infection. The time needed for elimination of bacteria was in average 2.8 ( \pm 1.0$)$ days. In conclusion, E. coli spp. provokes a positive cytology and most of the mares developed vaginal clinical signs of endometritis and IUF, with no difference among $E$. coli strains.
\end{abstract}

Keywords: mares / infection / E coli / endometritis / cytology / bacteriology / reproduction

Correspondence: Prof. R. C. Mattos, REPROLAB, Faculdade de Veterinária, UFRGS, Av. Bento Gonçalves 9090, 91570-000 Porto Alegre, RS, Brazil,E-mail: rcmattos@ufrgs.br

Citation: Camozzato G. C., Cazales N., Pinheiro E. M., Wolf C. A., Garbade P., Jobim M. I. M., Gregory R. C .M., Mattos RC. (2014) Endometritis in mares experimentally infected with three different strains of E. coli. Pferdeheilkunde 30, 57-60

\section{Introduction}

Endometritis is the most important cause of infertility in barren mares (Hughes and Loy 1975, LeBlanc et al. 2010) and inflicts major losses on the equine breeding industry. Bacterial uterine infections occur in $25 \%$ to $60 \%$ of barren mares and the most frequently isolated pathogens are Streptococcus zooepidemicus and Escherichia coli (Dimock 1928, Collins 1964, Mattos et al. 1984, Albihn 2003, LeBlanc et al. 2007 and LeBlanc $2011)$. Endometritis caused by Streptococcus sp has been widely studied (Hughes and Loy 1975, Neves et al. 2010). However, little is known about the mare's endometrial response to E. coli (LeBlanc et al. 2007 and Eaton 2010). Focal infection (LeBlanc et al. 2007) induced by E. coli (Eaton 2010) was associated with less exudative uterine inflammatory response than by Streptococcus zooepidemicus. In contrast some studies have shown that uterine infections by $\mathrm{E}$ coli were less likely to have cytological evidence of inflammation (Riddle et al. 2007, Burleson 2010). The objective of this study was to describe the uterine inflammatory response after intrauterine inoculation with three different strains of $\mathrm{E}$. coli in the mare.

\section{Materials and methods}

Animals

The experiment was conducted at the Laboratory of Animal Reproduction, UFRGS, Porto Alegre, Brazil. Nine cyclic mares between aged 7 and 20 years old were used. Mares were kept under similar conditions of management during all the experiment, supplemented with oats and hay twice a day with ad libitum access to water and mineral supplement.

\section{Bacteriological and cytological examinations}

To obtain the endometrial samples, the mare's perineum was washed and the tail bandaged. A guarded swab (Minitube $\mathrm{GmbH}$, Tiefenbach, Germany) was passed through the cervix into the uterine lumen, via a sterile speculum (Merkt and von Lepel 1970). The swab was exposed into the uterine lumen to obtain an endometrial sample without contamination. The swab was retracted into the sheath, removed from the uterus and immediately plated on Chromagar ${ }^{T M}$ (McKinnon 2011). A bacteriological culture was considered negative when no growth was observed on the Chromogenic Agar dish or insignificant contaminants were isolated.

Another swab was taken, in a similar manner, to make an endometrial smear for cytological examination (Mattos et al. 1984). The swab was rolled back on a clean microscope slide, fixed and stained with a Romanowsky stain (Panótico ${ }^{\circledR}$, Laborclin, Brazil) and evaluated under light microscopy $(400 \times)$. Cytology was considered negative when no PMNs were detected in the slide. Positive cytology was classified according to the number of PMNs in the observed fields as: severe $(>20)$, intense $(15-19)$, moderate $(10-14)$ and slight $(<10)$. 


\section{Clinical examination of the genital tract}

Mares were examined by transrectal palpation and ultrasonography to detect intrauterine fluid (IUF). The IUF was characterized by hypoechoic areas larger than $10 \mathrm{~mm}$ in diameter in the uterine lumen. Vaginal examination was performed to observe mucosa aspect and the presence of secretion. Vaginal clinical signs were classified as: severe (abundant fluid accumulation), mild (little fluid accumulation) or absent (without fluid accumulation).

\section{Preparation of bacteria}

Three different $E$. coli strains were obtained from: uterine swab of a mare with endometritis (UT), vestibular swab from a healthy mare (VE) and from mare's manure (MA). After isolation, bacteria were cultured for $24 \mathrm{~h}$ in the brain heart infusion $(\mathrm{BHI})$ enrichment medium. Glycerol was added to the BHI medium, stored in $20 \mathrm{~mL}$ sterile cryovials at $-20^{\circ} \mathrm{C}$. A resistance test for the three strains of $\mathrm{E}$. coli was performed and demonstrated differences in the antimicrobial susceptibility.

Before infusion, bacteria were thawed and incubated at $37^{\circ} \mathrm{C}$ for $24 \mathrm{~h}$ in $\mathrm{BHI}$ agar dishes in order to allow bacterial growth. For uterine inoculation, colonies were suspended in $2 \mathrm{~mL}$ saline solution to a final concentration of $1.5 \times 10^{9} \mathrm{bac}$ teria $/ \mathrm{mL}$, using the MacFarland scale $\left(\right.$ Neflobac ${ }^{\circledR}$, Probac do Brazil Ltda, São Paulo, Brazil).

\section{Experimental Design}

Before each experimental infection, mares were examined for reproductive soundness, including evaluation of perineal conformation, palpation per rectum and ultrasound of the genital tract, vaginal examination with speculum, bacteriological cultures and cytology of the endometrium. Only clinically normal mares with negative cytology and negative cultures were used.
When the presence of a dominant follicle $(>35 \mathrm{~mm})$ and uterine edema $(2-3)$ were detected, mares were experimentally infected with either one of the three strains of $\mathrm{E}$. Coli $\left(3 \times 10^{9}\right.$ CFU) diluted in a $20 \mathrm{~mL}$ saline solution. Only clinically healthy mares with negative cytology and bacteriology were used for this experiment. All mares were free from intrauterine fluid at the time of inoculation with $\mathrm{E}$. coli.

Clinical examinations of the genital tract, endometrial cytology and endometrial cultures were conducted daily on all mares, beginning 1 day after bacterial infusion. Clinical, bacteriological (Merkt and von Lepel 1970) and cytological (Mattos et al. 1984) examination continued until negative culture for $E$. coli from endometrial swabs and absence of neutrophils in cytology were detected.

A Latin square design was used. All mares were challenged with the three strains of $E$. coli in a randomized order in the subsequent cycles. As nine mares were used and each one was submitted to the three E. coli strains, a total of 27 infections were done. New infections were performed no sooner than 14 days following complete elimination of bacteria previously inoculated. No mare was lost during the process.

\section{Statistical analysis}

Data were analyzed using general linear model procedure of SAS (Statistical Analysis System). The model included the main effects of mare, E. coli strain and sequences of experimental groups and the dependent variables of time required to eliminate bacteria after experimental infection, time between experimental infection and the first negative cytology and their interactions. Means were compared using least square means.

\section{Results}

The percentage of mares with vaginal clinical signs, IUF values, positive cytology and bacteriology $24 \mathrm{~h}$ after experi-

Table 1 - Percentage of mares with positive cytology and bacteriology, with vaginal clinical signs and IUF $24 \mathrm{~h}$ after experimentally infection with three different strains of E coli. / Prozentualer Anteil der Stuten mit positiver Zytologie, vaginal klinischen Symptomen und intrauteriner Flüssigkeitsansammlung 24 Stunden nach experimenteller Infektion mit drei verschiedenen E. coli Stämmen

\begin{tabular}{ccccc}
\hline E coli strain & Vaginal & IUF ${ }^{*}$ & Positive Cytology & Positive Bacteriology \\
\hline UT & $78 \%^{a}$ & $89 \%^{a}$ & $100 \%$ & $67 \%{ }^{a}$ \\
VE & $100 \%^{a}$ & $89 \%^{a}$ & $100 \%$ & $67 \%{ }^{a}$ \\
MA & $100 \%^{a}$ & $100 \%^{a}$ & $100 \%$ & $44 \%{ }^{a}$ \\
\hline Mean & $92.6 \%$ & $92.6 \%$ & $100 \%$ & $59.3 \%$ \\
\hline
\end{tabular}

Different characters indicate significant difference in the column $(P<0.05) \quad *$ Intrauterine Fluid

Table 2 - Length of time (days) and standard deviation between experimental infection and the first negative cytology and bacteriology in mares experimentally infected with three different strains of E coli. / Zeitintervall (Tage mit Standardabweichung) zwischen experimenteller Infektion und der ersten negativen Zytologie und Bakteriologie bei Stuten nach experimenteller Infektion mit drei verschiedenen E. coli Stämmen

\begin{tabular}{ccc}
\hline E coli strain & Cytology (days) & Bacteriology (days) \\
\hline UT & $3.1^{a} \pm 0.9$ & 0.8 \\
VE & $3.6^{a} \pm 0.7$ & $3.8^{a} \pm 1.3$ \\
MA & $3.6^{a} \pm 0.9$ & 0.5 \\
\hline Mean & $3.4 \pm 0.8$ & $2.8 \pm 1.0$ \\
\hline
\end{tabular}


mentally infection with three different strains of $E$ coli are depicted in Table 1. In 25 of 27 mares (92.6\%), vaginal clinical signs and IUF were observed in the inoculated mares. Severe vaginal signs with purulent aspect and hyperemic mucosa were observed in 17, and the remaining 8 presented mild signs. However, one of the mares without clinical signs of endometritis presented IUF. At the third day, the number of mares presenting mild or severe clinical signs was reduced to 11 (40.7\%) (Figure 1).

All mares had slight ( $<10 /$ field) to severe ( $>20 /$ field) endometrial neutrophilia $24 \mathrm{~h}$ after $\mathrm{E}$ coli inoculation and the cytology remained positive 3.4 days in average (table 2). UT $E$. coli had a tendency $(P<0.09)$ to produce a higher neutrophilia than the VE and MA E. coli. Only 16 out of 27 mares $(59.3 \%)$ were positive for E coli culture $24 \mathrm{~h}$ after E coli inoculation. The time needed for $\mathrm{E}$. coli elimination was in average 2.81 days (table 2).

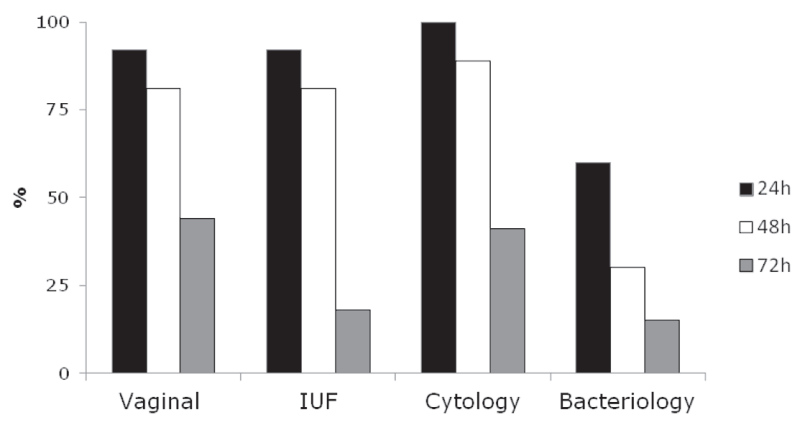

Fig 1 Occurrence of positive cytology, positive bacteriology, clinical signs of endometritis, and IUF $24 \mathrm{~h}, 48 \mathrm{~h}$ and $72 \mathrm{~h}$ after infection with E. coli. / Auftreten einer positiven Zytologie, einer positiven Bakteriologie, klinischen Symptomen und einer intrauterinen Flüssigkeitsansammlung $24 \mathrm{~h}, 48 \mathrm{~h}$ und $72 \mathrm{~h}$ nach Infektion mit $\mathrm{E}$. coli

\section{Discussion}

After 24 hours of intrauterine infection with three different strains of E. coli, all mares (100\%) presented slight to severe positive endometrial cytology. Twenty-five (92.6\%) out of 27 mares presented vaginal clinical signs and intrauterine fluid accumulation. This is in agreement with recent studies, where the presence of PMNs was observed in all mares and clinical signs of endometritis and IUF were present in $83 \%$ (Christoffersen et al. 2010) and in 100\% (Christoffersen et al. 2012) of the cases at $3 \mathrm{~h}, 24 \mathrm{~h}$ and $72 \mathrm{~h}$ after $\mathrm{E}$. coli infection. However, most of the authors have reported that not all positive cultures of $\mathrm{E}$. coli were associated with positive cytology (Riddle et al. 2007, Bindslev et al. 2008, Nielsen et al. 2010, Overback et al. 2011 ).

In the present study, positive bacterial culture was detected in $59.2 \%$ of the infected mares after $24 \mathrm{~h}$ of $\mathrm{E}$. coli inoculation. In this study the $\mathrm{E}$. coli isolation rates were lower than the obtained with experimental infection with Streptococcus sp (Neves et al. 2007), using the same technique. Uterine exudate in E. coli infections may be tenacious, similar to that reported for Klebsiella infections (Dimock and Edwards 1928, Beachey 1981), making it difficult to isolate on a culture swab. In chronic infections E. coli secrete a biofilm, a hydrated matrix of polysaccharide and protein, providing an adhesive matrix for micro-colonies (Costerton 1995, Freeman 1990). E. coli may also be associated with focal infection as endoscopic evaluation of the uterine lumen of two affected mares revealed focal, granulomatous plaques (LeBlanc et al. 2007). A low volume flush technique may identify more pathogenic organisms than the swab technique, as the saline solution comes in contact with a larger surface area (LeBlanc et al. 2007). The uterine flushing technique seems to have a higher sensitivity for the detection of gram-negative microorganisms, whereas for $\beta$-haemolytic Streptococcus, it did not differ when compared to swabs (Wingfield 1982 and Riddle 2007).

In an unpublished study (Camozzato 2013) isolated E. coli from the vulva and vestibule in $80 \%$ of the mares after cleaning the perineum with water and soap. The author demonstrated that is very easy to provoke a sample contamination with a simple touch of the swab in the vulvar-vestibular area. False positive cultures have been associated with contamination of culture instruments from the environment, external genitalia and vagina (Ricketts 1981). Contamination of a uterine catheter with vaginal flora must be considered as a source of false positive culture results, because contamination occurs more frequently in a semi-guarded (i.e. the flush technique) than in a completely guarded (i.e. swab technique) endometrial culture technique (LeBlanc et al. 2007).

In this study, no difference in cytology, vaginal and uterine clinical signs among the three different strains of E. Coli were observed. In cows with metritis, E. coli was more adherent and invasive to endometrial epithelial and stromal cells. Bicalho et al. (2010) reported six genes: fimH, ast $A$, cdt, kpsMII, ibeA and hlyA to be mostly associated with bacterial adhesion or invasion, in both metritis and clinical endometritis. The fimH adherence gene was present in $87 \%$ of the uterine $\mathrm{E}$. coli infections in cows and in $29 \%$ was strongly associated with increased risk of disease. In the present study, despite the differences among the three different strains, the bacteria used probably presented genes associated with adhesion or invasion and caused the clinical signs of endometritis and the positive cytology.

In conclusion, E. coli endometritis provoked a positive cytology and most of the mares developed vaginal clinical signs of endometritis and IUF, with no difference among E. coli strains.

\section{Acknowledgement}

The authors would like to thank the Microbiology Laboratory - Faculty of Veterinary - UFRGS. This study was financially supported by CAPES, CNPq and FAPERGS

\section{Conflict of interest statement}

The authors declare that they have no competing interests.

\section{References}

Albihn A., Baveurd U. (2003) Uterine microbiology and antimicrobial susceptibility in isolated bacteria from mares with fertility problems. Acta Vet. Scand. 121-129 
Beachey E. H. (1981) Bacterial-adherence: adhesion-receptor interactions mediating the attachment of bacteria to mucosal surfaces. J. Infect. Dis. 143, 45

Bicalho R. C., Machado, V. S., Bicalho, M. L., Gilbert, R. O., Teixeira, A. G., Caixeta, L. S., Pereira, R. V. (2010) Molecular and epidemiological char-acterization of bovine intrauterine Escherichia coli. J. Dairy Sci. 93, 5818-5830

Bucca S., Carli A., Buckley T., Dolci G., Fagarty U. (2013) Modulation of persistent mating induced endometritis in susceptible mares, by corticosteroid administration at breeding time. Reproducción equina III. Resumenes de conferencias del III congreso argentino de reproducción equina. Ed Unirío, 89-96

Burleson M. D., LeBlanc M. M., Riddle W. T., Hendrikis K. E. M. (2010) Endometrial microbial isolates are associated with different ultrasonographic and endometrial cytology findings in Thoroughbred mares. Anim. Reprod. Sci. 121-103

Collins S. M. (1964) A study of the incidence of cervical and uterine infections in thoroughbred mares in Ireland. Vet. Rec. 76, 673-675

Costerton J. W., Lewandowski Z., Caldwell D. E., Korber D. R., Lappin-Scott H. M. (1992) Microbial biofilms Ann Rev Microbiol $p$ 711-745, (1995) In: Darenius K. Early foetal death in the mare Histological, bacteriological and cytological findings in the endometrium. Acta Vet. Scand. 33, 147-160

Christoffersen M., Baagoe C. D., Jacobsen S., Bojesen A. M., Petersen M. R., Lehn-Jensen H. (2010) Evaluation of the systemic acute phase response and endometrial gene expression of serum amyloid $A$ and pro- and anti-inflammatory cytokines in mares with experimentally induced endometritis. Vet. Immunol. Immunopathol. 138, 95-105

Christoffersen M., Woodward E. M., Bojesen A. M., Petersen M.R., Squires E. L., Lehn-Jensen H., Troedsson M. H. T. (2012) Effect of immunomodulatory therapy on the endometrial inflammatory response to induced infectious endometritis in susceptible mares. Theriogenology 78, 991-1004

Dimock W. W., Edwards P. R. (1928) The pathology and bacteriology of the Reproductive organs of mares in relation to sterility. 286, 157-237

Eaton S., Raz T., Chirino-Trejo M., Bergermann J., Card C. (2010) Comparison of endometrial inflammation following intrauterine inoculation with genital strains of Streptococcus equi subsp zooepidemicus or Escherichia coli in the mare. Anim. Reprod. Sci.121, 101-102

Freeman K. P., Roszel J. F., Slusher S. H., Castro M. (1990) Variation in glycogen and mucins in the equine uterus related to physiologic and pathologic conditions. Theriogenology 33, 799-808

Kenney R. M., Doig P. A. (1986) Equine endometrial biopsy In: Morrow DA Current Therapy. In: Theriogenology. W. B. Saunders Comp. 723-729

Hughes J., Pand Loy R. G. (1969) Investigations on the effect of intrauterine inoculations of Streptococcus zooepidemicus in the mare. American Association of Equine Practitioners. 289-292

Le Blanc M. M., Magsig J., Stromberg A. J. (2007) Use of a low-volume uterine flush for diagnosing endometritis in chronically infertile mares. Theriogenology. 68, 403-412

LeBlanc M. M. (2010) Advances in the Diagnosis and Treatment of Chronic Infectious and Post Mating-Induced Endometritis in the Mare. Reprod. Dom. Anim. 45, 21-27

Mattos R. C., Mattos A. L. G., Gunzel A. R., Klug E. (1984) Bakteriologische und zytologische Untersuchungen von Uterusabstrichen beim Pferd. Prak. Tierarzt 65, 809-814
McKinnon A. O., Beehan D. P. (2011) Use of Chromogenic Agar to Diagnose Reproductive Pathogens. In: McKinnon A. O., Equine reproduction. 2, 1979-1987

Merkt H., von Lepel J. F. (1970) Die Entnahme von probenf"ur die bakteriologischeUntersuchung des Genitalsekretes der Stute, ihre Beurteilungsowie Behandlungshinweise Dtsch. Tierärztl. Wsch. 77, 489-528

Overbeck W., Witte T. S., Heuwieser W. (2011) Comparison of three diagnostic methods to identify subclinical endometritis in mares. Theriogenology 75, 1311-1318

Riddle W. T., LeBlanc M. M., Stromberg A. J. (2007) Relationships between uterine culture, cytology and pregnancy rates in a thoroughbred practice. Theriogenology 68, 395-402

Ricketts S. W. (1981) Bacteriological examinations of the mare's cervix: techniques and interpretation of results. Vet. Rec.108, 46-51

Wingfield-Digby N. J., Ricketts S. W. (1982) Results of concurrent bacteriological and cytological examinations of the endometrium of mares in routine stud farm practice. J. Reprod. Ferti.|32, 181-185

Endometritis bei mit drei unterschiedlichen Stämmen von E-coli experimentell infizierten Stuten

Das Ziel dieser Studie war es, Entzündungsreaktion bei der Stute zu beschreiben, die nach intrauteriner Inokulation mit drei verschiedenen Stämmen von E. coli auftreten. Neun zyklische Stuten im Alter zwischen 7 und 20 Jahren wurden ausgewählt und ihr Östrus durch transrektale Palpation und Ultraschall ermittelt. Nur klinisch unauffällige Stuten mit negativer Zytologie und Bakteriologie wurden verwendet. Drei verschiedene Stämme von E. coli kamen zum Einsatz: (UT) aus einer Tupferprobe einer Stute mit Endometritis, (VE) aus einem vestibulären Tupfer einer gesunden Stute und (MA) aus Pferdemist. Anschließend wurden die Stuten intrauterin mit $3 \times 10^{9} \mathrm{E}$. coli einer der drei Stämme inokuliert. Alle Stuten wurden mit jedem Stamm von E. coli in randomisierter Reihenfolge in den folgenden Zyklen infiziert. Einen Tag nach der Infektion erfolgte eine klinische Untersuchung des Genitaltrakts mittels Spekulum, sowie Ultraschall, Endometriumzytologie und bakteriologische Kultur. Diese Verfahren wurden täglich so lange wiederholt bis eine negative Kultur und negative Zytologie diagnostiziert werden konnte. Alle Stuten hatten $24 \mathrm{~h}$ nach der E. coli Inokulation wenige ( $<10 /$ Gesichtfeld) bis zahlreiche ( $>20 /$ Gesichtsfeld) neutrophile Granulozyten im Endometrium. 25 von 27 Stuten (92,6\%) zeigten vaginal klinische Anzeichen und eine intrauterine Flüssigkeit (IUF). Schwere vaginale Symptome mit eitrigen Charakter und hyperämischer Schleimhaut lagen bei 17 Stuten und milde Erscheinungen bei 8 Stuten vor. Nur 59,2\% der Stuten $(16 / 27)$ erwiesen sich $24 \mathrm{~h}$ nach der Infektion als E. coli positiv. Die durchschnittliche Zeit für die Beseitigung der Bakterien lag bei 2,8 $( \pm 1,0)$ Tagen. Abschließend ist festzustellen, dass E. coli spp. eine positive Zytologie provozieren und die meisten Stuten vaginal klinische Anzeichen einer Endometritis und IUF entwikkeln, wobei kein Unterschied zwischen den E. coli-Stämmen zu erkennen ist.

Schlüsselwörter: Stute / Infektion / E.coli / Endometritis / Zyłologie / Bakteriologie / Reproduktion 